\title{
PENGARUH PEMBERIAN NATA DE COCO TERHADAP KADAR KOLESTEROL TOTAL PADA WANITA HIPERKOLESTEROLEMIA
}

\author{
Ni Putu Ratih Purwani, Tatik Mulyati*) \\ Program Studi Ilmu Gizi Fakultas Kedokteran Universitas Diponegoro \\ Jl.Dr.Sutomo No.14, Semarang, Telp (024) 8453708, Email : gizifk@undip.ac.id
}

\begin{abstract}
Background : Hypercholesterolemia have been shown to be one of the factors associated with cardiovascular disease. Consumption of high dietary fiber can reduce the total cholesterol level in blood. Nata de coco is a fiber rich food, contain cellulose, hemicellulose and lignin that can reduce serum cholesterol level.

Methods : This research was true experimental study with control group pre-test post-test design. Subjects were women with serum total cholesterol level $\geq 200 \mathrm{mg} / \mathrm{dl}$, classified into 3 groups, control, group 1 consume $160 \mathrm{~g}$ nata de coco/day (with $4.8 \mathrm{~g}$ of fiber) and group 2 consume $320 \mathrm{~g}$ nata de coco/day (with $9.6 \mathrm{~g}$ of fiber). Nata de coco was consumed during 14 days. Blood was collected after an overnight fast. Serum total cholesterol level was measured with CHOD-PAP method. Shapiro-Wilk was used to analyze normality of the data. The statistical analyzes include paired-t test and Kruskal-Wallis test.

Results : Consumption $160 \mathrm{~g} /$ day (with $4.8 \mathrm{~g}$ of fiber) dan $320 \mathrm{~g} /$ day (with $9.6 \mathrm{~g}$ of fiber) of nata de coco can reduce total cholesterol level $5.17 \%(p=0.049)$ and $6.59 \%(p=0.011)$ respectively, but there was no difference of decreased cholesterol level between first and second group $(p=0.857)$. In control group, there was an increase of total cholesterol level for $1.7 \%(p=0.024)$.

Conclusions : Consumption of nata de coco can reduce serum total cholesterol level in women with hypercholesterolemia, but there is no difference effect between the first and second group.
\end{abstract}

Keyword : nata de coco; serum total cholesterol; women; hypercholesterolemia

\begin{abstract}
ABSTRAK
Latar Belakang : Hiperkolesterolemia merupakan salah satu faktor risiko terjadinya penyakit jantung dan pembuluh darah. Konsumsi makanan tinggi serat dapat menurunkan risiko penyakit jantung dan pembuluh darah. Nata de coco mengandung selulosa, hemiselulosa dan lignin yang berperan dalam menurunkan kadar kolesterol total dalam darah.

Metode : Jenis penelitian adalah true experimental dengan rancangan control group pre-test-post-test. Subyek adalah wanita hiperkolesterolemia dengan kadar kolesterol total $\geq 200 \mathrm{mg} / \mathrm{dl}$, dibagi menjadi 3 kelompok, yaitu kelompok kontrol, kelompok perlakuan 1 mendapat $160 \mathrm{~g}$ nata de coco/hari (serat $4.8 \mathrm{~g}$ ) dan perlakuan 2 mendapat $320 \mathrm{~g}$ nata de coco/hari (serat $9.6 \mathrm{~g}$ ). Intervensi dilakukan selama 14 hari. Metode CHOD-PAP digunakan untuk menganalisis kadar kolesterol total, darah diambil setelah subyek berpuasa selama 10 jam. Uji normalitas menggunakan Shapiro-Wilk. Analisis statistik menggunakan uji paired-samples t test dan uji Kruskal-Wallis.

Hasil : Konsumsi nata de coco dengan dosis $160 \mathrm{~g} / \mathrm{hari}$ (serat $4.8 \mathrm{~g}$ ) dan $320 \mathrm{~g} / \mathrm{hari}$ (serat $9.6 \mathrm{~g}$ ) dapat menurunkan kadar kolesterol total berturut-turut sebesar $5.17 \%(p=0.049)$ dan $6.59 \%(p=0.011)$, namun tidak ada perbedaan penurunan kadar kolesterol total antara kedua kelompok $(p=0.857)$. Sedangkan pada kelompok kontrol terjadi peningkatan kadar kolesterol total sebesar 1.7\% ( $p=0.024)$.

Kesimpulan : Konsumsi nata de coco berpengaruh terhadap penurunan kadar kolesterol total pada wanita hiperkolesterolemia, namun tidak ada perbedaan penurunan kadar kolesterol total antara kedua kelompok.
\end{abstract}

Kata kunci : nata de coco; kolesterol total; wanita; hiperkolesterolemia

\section{PENDAHULUAN}

Hiperkolesterolemia merupakan salah satu faktor risiko terjadinya penyakit jantung dan pembuluh darah. ${ }^{1,2}$ Prevalensi nasional penyakit jantung di Indonesia menurut RISKESDAS 2007 adalah $7,2 \%$, sementara prevalensi penyakit jantung di provinsi Jawa Tengah sebesar 8,4\%. ${ }^{3}$

Serat dapat menurunkan risiko penyakit jantung dan pembuluh darah melalui mekanisme pengaturan konsentrasi lipid dalam darah, yaitu pengikatan garam empedu dan kolesterol di dalam usus, meningkatkan pengeluaran empedu melalui feses, menurunkan aktivitas enzim pencernaan seperti amilase, tripsin, kimotripsin dan lipase, serta menghasilkan senyawa asam lemak jenuh rantai pendek yang dapat menurunkan sintesis asam lemak dan kolesterol. ${ }^{4,5,6}$

${ }^{*}$ Penulis Penanggungjawab 
Pemberian suplemen kombinasi serealia dan $40 \%$ serat nata de coco dengan kandungan serat pangan 2,7 g/hari selama 20 minggu diketahui dapat menurunkan kadar kolesterol total sebesar $8,8 \% .^{7}$ Sementara pemberian nata de coco kering pada tikus Sprague Dawley hiperkolesterolemia dengan kandungan serat $0,18 \mathrm{~g} ; 0,36 \mathrm{~g} ; 0,54 \mathrm{~g}$ dan $0,72 \mathrm{~g}$ per hari selama 2 minggu dapat menurunkan kadar kolesterol total secara signifikan berturutturut $18,22 \% ; 32,62 \% ; 36,76 \%$ dan $41,98 \%{ }^{8}$

Nata de coco merupakan produk hasil fermentasi air kelapa oleh bakteri yang memiliki kandungan serat tinggi. Jenis serat pangan yang terkandung dalam nata de coco antara lain selulosa, hemiselulosa dan lignin. ${ }^{7,8}$ Selulosa berperan dalam menurunkan aktivitas enzim amilase, lipase, tripsin dan kimotripsin serta dapat difermentasi untuk menghasilkan asam lemak jenuh rantai pendek. $^{5} \quad$ Lignin terbukti mampu menurunkan risiko pembentukan batu empedu, mengikat asam lemak, empedu dan kolesterol, serta meningkatkan ekskresi empedu pada hamster. ${ }^{5,6}$ Sementara hemiselulosa diketahui mampu menurunkan kadar kolesterol total dalam serum dan menghasilkan asam lemak jenuh rantai pendek sebagai hasil fermentasi di dalam kolon. ${ }^{6,9}$

Sebuah studi cross-sectional yang dilakukan di Thailand menunjukkan bahwa prevalensi hiperkolesterolemia pada pria dan wanita memberikan hasil yang hampir sama dan sebanyak 50,3\% wanita hiperkolesterolemia didominasi pada kelompok usia 30-49 tahun. $^{10}$ Sementara rendahnya aktivitas fisik merupakan salah satu faktor risiko yang dapat mempengaruhi kadar kolesterol total. $^{2}$

Penelitian mengenai pengaruh pemberian nata de coco kering pada hewan coba serta pemberian suplemen gabungan serat serealia dan nata de coco pada manusia dengan hiperlipidemia telah dilakukan, namun penelitian tentang pemberian nata de coco basah terhadap manusia dengan hiperkolesterolemia belum dilakukan. Hal inilah yang mendasari dilakukannya penelitian ini, dengan mengambil subyek wanita usia subur. Pemilihan subyek penelitian di lingkungan kerja kantor Sekretariat Daerah Provinsi Jawa Tengah dan kantor Badan Perencanaan Pembangunan Provinsi Jawa Tengah dianggap dapat mewakili populasi dengan aktivitas fisik rendah.

\section{METODE}

Penelitian ini merupakan penelitian true experimental dengan rancangan control group pretest-post-test. Variabel bebas dalam penelitian ini adalah dosis nata de coco, sementara variabel terikat adalah kadar kolesterol total penderita hiperkolesterolemia.

Subyek penelitian merupakan karyawati kantor Sekretariat Daerah Provinsi Jawa Tengah dan karyawati kantor Badan Perencanaan Pembangunan Provinsi Jawa Tengah, dengan kriteria inklusi memiliki kadar kolesterol total $\geq$ $200 \mathrm{mg} / \mathrm{dl}$, berusia minimal 30 tahun, belum menopause, tidak sedang mengkonsumsi obat antihiperlipidemia dan tidak dalam keadaan sakit atau dalam perawatan dokter berkaitan dengan penyakit jantung koroner, diabetes melitus, hipertensi, dan penyakit kronik lainnya. Perhitungan subyek penelitian menggunakan rumus uji hipotesis terhadap rerata dua populasi independen dan dibutuhkan sebanyak 54 subyek.

Penentuan subyek penelitian menggunakan metode consecutive sampling. Sebanyak 82 orang bersedia diambil darahnya untuk proses skrining awal dan diperoleh sebanyak 54 orang yang memenuhi kriteria inklusi untuk menjadi subyek penelitian. Subyek dibagi menjadi 3 kelompok dengan metode simple random sampling, yang terdiri atas satu kelompok kontrol dan dua kelompok perlakuan, masing-masing kelompok terdiri atas 18 subyek. Kelompok perlakuan pertama mendapatkan nata de coco sebanyak 160 $\mathrm{g} /$ hari dengan kandungan serat $4.8 \mathrm{~g}$ dan kelompok perlakuan kedua mendapatkan nata de coco sebanyak 320 /hari dengan kandungan serat 9.6 g.

Pemberian nata de coco dilakukan selama 14 hari, sementara pada kelompok kontrol, subyek tidak diberikan perlakuan. Konsumsi makan sehari-hari, baik untuk kelompok kontrol maupun kelompok perlakuan tidak dikontrol dan dibiarkan sebagaimana biasa. Pencatatan asupan makan dilakukan sebelum dan selama intervensi. Sementara kepatuhan mengkonsumsi nata de coco dikontrol dengan menggunakan formulir daya terima. Tidak ada subyek yang drop out dalam penelitian ini.

Kandungan serat dalam nata de coco yang digunakan dalam penelitian ini yaitu 3\%. Nilai ini hampir mendekati kandungan serat dalam nata de coco yang digunakan dalam penelitian terdahulu, yaitu $3.122 \% .{ }^{8}$ Gula nata de coco tidak digunakan selama intervensi.

Kadar kolesterol total dianalisis dengan pemeriksaan laboratorium menggunakan metode Cholesterol Oxidase Phenol Aminoantipyrin (CHOD-PAP). Darah diambil oleh petugas laboratorium setelah subyek berpuasa selama \pm 10 
jam. Sementara data asupan makan subyek dianalisis menggunakan program nutrisurvey 2005.

Uji normalitas menggunakan uji ShapiroWilk. Karakteristik subyek dianalisis dengan menggunakan analisis deskriptif. Perbedaan kadar kolesterol total sebelum dan sesudah perlakuan dianalisis dengan menggunakan uji paired-samples $t$ test, sedangkan perbedaan perubahan kadar kolesterol total antar tiga kelompok dianalisis dengan uji Kruskal-Wallis.

\section{HASIL PENELITIAN \\ Karakteristik Subyek}

Karakteristik subyek yang terdiri dari gambaran umur, status gizi dan kadar kolesterol total subyek sebelum penelitian disajikan dalam tabel 1. Seluruh subyek adalah wanita dengan usia $>30$ tahun dan belum menopause.

Tabel 1. Karakteristik subyek

\begin{tabular}{|c|c|c|c|c|c|c|c|}
\hline \multirow{2}{*}{ Karakteristik subyek } & \multicolumn{2}{|c|}{$\begin{array}{c}\begin{array}{c}\text { Kontrol } \\
(\mathrm{n}=18)\end{array} \\
\end{array}$} & \multicolumn{2}{|c|}{$\begin{array}{c}\begin{array}{c}\text { Perlakuan } 1 \\
(n=18)\end{array} \\
\end{array}$} & \multicolumn{2}{|c|}{$\begin{array}{c}\begin{array}{c}\text { Perlakuan } 2 \\
(n=18)\end{array} \\
\end{array}$} & \multirow[t]{2}{*}{$\mathbf{P}^{\mathbf{a}}$} \\
\hline & $\mathrm{n}$ & $\%$ & $\mathrm{n}$ & $\%$ & $\mathrm{~N}$ & $\%$ & \\
\hline \multicolumn{8}{|l|}{ Umur } \\
\hline 30-39 tahun & 1 & $5.6 \%$ & - & - & 2 & $11.1 \%$ & \multirow{3}{*}{0.588} \\
\hline 40-49 tahun & 10 & $55.6 \%$ & 12 & $66.7 \%$ & 11 & $61.1 \%$ & \\
\hline 50-59 tahun & 7 & $38.9 \%$ & 6 & $33.3 \%$ & 5 & $27.8 \%$ & \\
\hline \multicolumn{8}{|l|}{ Status Gizi } \\
\hline$(18,5-22,9$ & 8 & $44.4 \%$ & 4 & $22.2 \%$ & 5 & $27.8 \%$ & \multirow{6}{*}{0.162} \\
\hline $\left.\mathrm{kg} / \mathrm{m}^{2}\right)$ & 4 & $22.2 \%$ & 6 & $33.3 \%$ & 3 & $16.7 \%$ & \\
\hline Overweight & 5 & $27.8 \%$ & 5 & $27.8 \%$ & 5 & $27.8 \%$ & \\
\hline $\left.\mathrm{kg} / \mathrm{m}^{2}\right)$ & 1 & $5.6 \%$ & 3 & $16.7 \%$ & 5 & $27.8 \%$ & \\
\hline $\begin{array}{l}\text { Obesitas } \\
\left.\mathrm{kg} / \mathrm{m}^{2}\right)\end{array} \quad$ I $\quad(25-29,9$ & & & & & & & \\
\hline \multicolumn{7}{|l|}{ Obesitas II $\left(\geq 30 \mathrm{~kg} / \mathrm{m}^{2}\right)$} & \\
\hline & \multicolumn{2}{|c|}{$\begin{array}{c}\text { Kontrol } \\
(\text { mean } \pm \text { SD })\end{array}$} & \multicolumn{2}{|c|}{$\begin{array}{c}\text { Perlakuan I } \\
(\text { mean } \pm \text { SD })\end{array}$} & \multicolumn{2}{|c|}{$\begin{array}{c}\text { Perlakuan } 2 \\
(\text { mean } \pm \text { SD })\end{array}$} & $\mathbf{P}^{\mathbf{a}}$ \\
\hline $\begin{array}{lll}\text { Kadar } & \text { kolesterol } & \text { total } \\
\text { awal } & & \\
(\mathrm{mg} / \mathrm{dl}) & & \\
\end{array}$ & \multicolumn{2}{|c|}{$230.56 \pm 22.64$} & \multicolumn{2}{|c|}{$243.28 \pm 26.01$} & \multicolumn{2}{|c|}{$237.28 \pm 25.42$} & $0.309^{\mathrm{a}}$ \\
\hline
\end{tabular}

${ }^{a}$ Uji beda ANOVA

Sebagian besar subyek dalam penelitian ini berada pada kelompok umur 40-49 tahun dan memiliki kategori status gizi overweight, obesitas 1 dan obesitas 2. Namun demikian, hasil uji beda menunjukkan tidak ada perbedaan umur, status gizi dan kadar kolesterol total awal antara ketiga kelompok ( $\mathrm{p}>0.05)$.

\section{Asupan makan sebelum intervensi}

Uji beda asupan makan dan kadar kolesterol total awal antar kelompok dilakukan untuk mengetahui homogenitas subyek sebelum intervensi.

Tabel 2. Asupan makan sebelum intervensi

\begin{tabular}{lcccc}
\hline & $\begin{array}{c}\text { Kontrol } \\
(\mathbf{n = 1 8})\end{array}$ & $\begin{array}{c}\text { Perlakuan 1 } \\
(\mathbf{n = 1 8})\end{array}$ & $\begin{array}{c}\text { Perlakuan 2 } \\
(\mathbf{n = 1 8})\end{array}$ & P \\
\hline Energi (kkal) & $1467.85 \pm 231.64$ & $1423.69 \pm 344.08$ & $1513.09 \pm 282.23$ & $0.654^{1}$ \\
Protein (g) & $47.57 \pm 12.13$ & $44.06 \pm 14.42$ & $54.79 \pm 15.89$ & $0.080^{1}$ \\
Lemak (g) & $49.72 \pm 15.52$ & $56.31 \pm 23.34$ & $55.67 \pm 18.86$ & $0.540^{1}$ \\
Karbohidrat (g) & $211.08 \pm 36.74$ & $190.33 \pm 42.10$ & $206.19 \pm 43.01$ & $0.288^{1}$ \\
Kolesterol (mg) & $178.61 \pm 121.65$ & $133.29 \pm 118.33$ & $123.08 \pm 82.14$ & $0.365^{2}$ \\
Serat (g) & $9.07 \pm 3.21$ & $9.01 \pm 2.38$ & $10.55 \pm 5.31$ & $0.399^{1}$ \\
\hline
\end{tabular}

1 Uji beda ANOVA

2 Uji beda Kruskal-Wallis 
Berdasarkan hasil pada tabel 2, diperoleh tidak ada perbedaan asupan dan kadar kolesterol total antara ketiga kelompok sebelum dilakukan intervensi. Sehingga dapat disimpulkan bahwa karakteristik awal subyek dalam penelitian ini tergolong homogen $(\mathrm{p}>0.05)$.

\section{Asupan makan selama intervensi dan kadar kolesterol total setelah intervensi}

Asupan energi, protein, lemak, karbohidrat, kolesterol dan serat dapat mempengaruhi kadar kolesterol total. Asupan makan subyek selama intervensi dapat dilihat pada tabel 3.

Tabel 3. Asupan makan dan kadar kolesterol total selama intervensi

\begin{tabular}{|c|c|c|c|c|}
\hline Zat Gizi & $\begin{array}{c}\begin{array}{c}\text { Kontrol } \\
(\mathrm{n}=18)\end{array} \\
\end{array}$ & $\begin{array}{c}\text { Perlakuan } 1 \\
(\mathrm{n}=18)\end{array}$ & $\begin{array}{c}\begin{array}{c}\text { Perlakuan } 2 \\
(n=18)\end{array} \\
\end{array}$ & $\mathbf{P}$ \\
\hline Energi (kkal) & $1470.47 \pm 223.95$ & $1408.2 \pm 230.69$ & $1420.4 \pm 262.51$ & $0.712^{1}$ \\
\hline Protein $(\mathrm{g})$ & $45.79 \pm 9.4$ & $45.63 \pm 8.92$ & $47.44 \pm 13.27$ & $0.755^{2}$ \\
\hline Lemak (g) & $49.11 \pm 8.29$ & $49.61 \pm 14.93$ & $49.34 \pm 10.52$ & $0.951^{2}$ \\
\hline Karbohidrat (g) & $213.98 \pm 40.87$ & $202.73 \pm 30.56$ & $210.33 \pm 43.53$ & $0.676^{1}$ \\
\hline Kolesterol (mg) & $163.85 \pm 67.12$ & $154.93 \pm 84.39$ & $146.30 \pm 82.18$ & $0.798^{1}$ \\
\hline Serat $(\mathrm{g})$ & $9.61 \pm 3.49$ & $14.49 \pm 2.59$ & $19.54 \pm 2.76$ & $0.000^{1}$ \\
\hline $\begin{array}{l}\text { Kadar } \\
(\mathrm{mg} / \mathrm{dl})\end{array}$ & $234.56 \pm 22.64$ & $229.39 \pm 27.06$ & $220.61 \pm 26.36$ & $0.262^{1}$ \\
\hline
\end{tabular}

1 Uji beda ANOVA

2 Uji beda Kruskal-Wallis

Berdasarkan hasil uji beda, tidak ada perbedaan asupan energi, protein, lemak, karbohidrat dan kolesterol antar ketiga kelompok, namun terdapat perbedaan asupan serat selama intervensi. Adanya perbedaan asupan serat antara ketiga kelompok disebabkan karena pengaruh pemberian nata de coco. Kadar kolesterol total subyek antara ketiga kelompok setelah intervensi juga tidak menunjukkan perbedaan.

Perubahan asupan makan sebelum dan selama intervensi

Perubahan asupan makan sebelum dan selama intervensi antara ketiga kelompok disajikan pada tabel 4 .

Tabel 4. Perubahan asupan makan sebelum dan selama intervensi

\begin{tabular}{lcccc}
\hline \multicolumn{1}{c}{ Zat Gizi } & $\begin{array}{c}\text { Kontrol } \\
(\mathbf{n = 1 8})\end{array}$ & $\begin{array}{c}\text { Perlakuan 1 } \\
(\mathbf{n = 1 8})\end{array}$ & $\begin{array}{c}\text { Perlakuan 2 } \\
(\mathbf{n = 1 8})\end{array}$ & $\mathbf{P}$ \\
\hline$\Delta$ Energi $(\mathrm{kkal})$ & $2.62 \pm 254.26$ & $-15.47 \pm 322.76$ & $-92.71 \pm 355.00$ & $0.628^{1}$ \\
$\Delta$ Protein $(\mathrm{g})$ & $-1.78 \pm 15.91$ & $1.57 \pm 12.02$ & $-7.35 \pm 14.59$ & $0.177^{1}$ \\
$\Delta$ Lemak $(\mathrm{g})$ & $-0.61 \pm 15.46$ & $-6.7 \pm 23.98$ & $-6.34 \pm 20.13$ & $0.600^{1}$ \\
$\Delta$ Karbohidrat & $2.9 \pm 43.52$ & $12.39 \pm 35.73$ & $-14.98(-67.77-$ & $0.404^{2}$ \\
$(\mathrm{~g})$ & $-14.76 \pm 133.70$ & $21.64 \pm 130.77$ & $129.03)$ & $0.581^{1}$ \\
$\Delta$ Kolesterol & $0.54 \pm 5.00$ & $5.49 \pm 2.46$ & $23.22 \pm 102.16$ & $0.000^{2^{*}}$ \\
$($ mg) & & & $8.99 \pm 5.28$ & \\
$\Delta$ Serat $(\mathrm{g})$ & & & & \\
\hline
\end{tabular}

1 Uji beda ANOVA 2 Uji beda Kruskal-Wallis *Beda bermakna

Berdasarkan tabel 4, tidak ada perbedaan perubahan asupan energi, protein, lemak, karbohidrat dan kolesterol, namun terdapat perbedaan perubahan asupan serat antara ketiga kelompok.

\section{Perbedaan asupan makan sebelum dan selama intervensi}

Perbedaan asupan makan subyek sebelum dan selama intervensi ditampilkan pada tabel 5 .

Tabel 5. Perbedaan asupan makan sebelum dan selama intervensi

\begin{tabular}{clccc}
\hline Kelompok & Zat Gizi & Asupan Pre & Asupan Selama & $\mathbf{P}^{\mathbf{a}}$ \\
\hline \multirow{2}{*}{ Kontrol } & Energi (kkal) & $1467.85 \pm 231.64$ & $1470.47 \pm 223.95$ & 0.966 \\
& Protein (g) & $47.57 \pm 12.13$ & $45.79 \pm 9.4$ & 0.641 \\
\hline
\end{tabular}




\begin{tabular}{clccc}
\hline & Lemak (g) & $49.72 \pm 15.52$ & $49.11 \pm 8.29$ & 0.869 \\
& Karbohidrat & $211.08 \pm 36.74$ & $213.98 \pm 40.87$ & 0.781 \\
& (g) & $178.61 \pm 121.65$ & $163.85 \pm 67.12$ & 0.645 \\
& Kolesterol & $9.07 \pm 3.21$ & $9.61 \pm 3.49$ & 0.652 \\
& (mg) & & & \\
& Serat (g) & & & \\
\hline Perlakuan I I & Energi (kkal) & $1423.69 \pm 344.08$ & $1408.2 \pm 230.69$ & 0.841 \\
& Protein (g) & $44.06 \pm 14.42$ & $45.63 \pm 8.92$ & 0.586 \\
& Lemak (g) & $56.31 \pm 23.34$ & $49.61 \pm 14.93$ & 0.252 \\
& Karbohidrat & $190.33 \pm 42.10$ & $202.73 \pm 30.56$ & 0.159 \\
& (g) & $133.29 \pm 118.33$ & $154.93 \pm 84.39$ & 0.492 \\
& Kolesterol & $9.01 \pm 2.38$ & $14.49 \pm 2.59$ & $0.000^{*}$ \\
& (mg) & & & \\
\hline Perlakuan & Energi (kkal) & $1513.09 \pm 282.23$ & $1420.4 \pm 262.51$ & 0.283 \\
II & Protein (g) & $54.79 \pm 15.89$ & $47.44 \pm 13.27$ & 0.048 \\
& Lemak (g) & $55.67 \pm 18.86$ & $49.34 \pm 10.52$ & 0.199 \\
& Karbohidrat & $206.19 \pm 43.01$ & $210.33 \pm 43.53$ & 0.769 \\
& (g) & $123.08 \pm 82.14$ & $146.30 \pm 82.18$ & 0.348 \\
& Kolesterol & $10.55 \pm 5.31$ & $19.54 \pm 2.76$ & $0.000^{*}$ \\
& (mg) & & & \\
\hline Serat (g) & & & \\
\hline
\end{tabular}

a Uji paired samples t test * Beda bermakna

Berdasarkan tabel 5, dapat dilihat bahwa tidak terdapat perbedaan asupan energi, protein, lemak, karbohidrat dan kolesterol sebelum dan selama intervensi antara ketiga kelompok. Perbedaan bermakna terjadi pada asupan serat sebelum dan sesudah intervensi, yaitu pada kelompok perlakuan I dan II.

Pengaruh konsumsi nata de coco terhadap kadar kolesterol total

Pengaruh konsumsi nata de coco terhadap kadar kolesterol total disajikan dalam tabel 6.

Tabel 6. Pengaruh konsumsi nata de coco terhadap kadar kolesterol total

\begin{tabular}{ccccccc}
\hline Kelompok & $\mathbf{N}$ & $\begin{array}{c}\text { Kolesterol } \\
\text { Total Awal } \\
(\mathbf{m g} / \mathbf{d l})\end{array}$ & $\begin{array}{c}\text { Kolesterol } \\
\text { Total Akhir } \\
(\mathbf{m g} / \mathbf{d l})\end{array}$ & $\begin{array}{c}\Delta \text { Kol.Total } \\
(\mathbf{m g} / \mathbf{d l})\end{array}$ & $\Delta \%$ & $\mathbf{P}^{*}$ \\
\hline Kontrol & 18 & $230.56 \pm 22.64$ & $234.56 \pm 22.85$ & $-4.00 \pm 6.84$ & 1.7 & 0.024 \\
Perlakuan 1 & 18 & $243.28 \pm 26.01$ & $229.39 \pm 27.06$ & $13.89 \pm 27.81$ & 5.17 & 0.049 \\
Perlakuan 2 & 18 & $237.28 \pm 25.42$ & $220.61 \pm 26.36$ & $15.50 \pm 25.40$ & 6.59 & 0.011 \\
\hline
\end{tabular}

*Uji beda paired-samples $t$ test

Hasil uji beda pada tabel 6 menunjukkan adanya perbedaan kadar kolesterol total sebelum dan setelah perlakuan yang bermakna $(\mathrm{p}<0.05)$. Penurunan kolesterol total pada kelompok perlakuan 1 dan 2 berturut-turut sebesar $5.17 \%$ dan $6.59 \%$. Sedangkan pada kelompok kontrol, terjadi peningkatan kadar kolesterol total sebesar $1.7 \%$.
Pengaruh konsumsi nata de coco terhadap rerata perubahan kolesterol total

Perbedaan rerata perubahan kolesterol total antar ketiga kelompok dianalisis dengan uji Kruskal-Wallis, sementara perbedaan rerata perubahan kolesterol total antara kelompok perlakuan 1 dan 2 dianalisis dengan uji independent-samples $t$ test. 


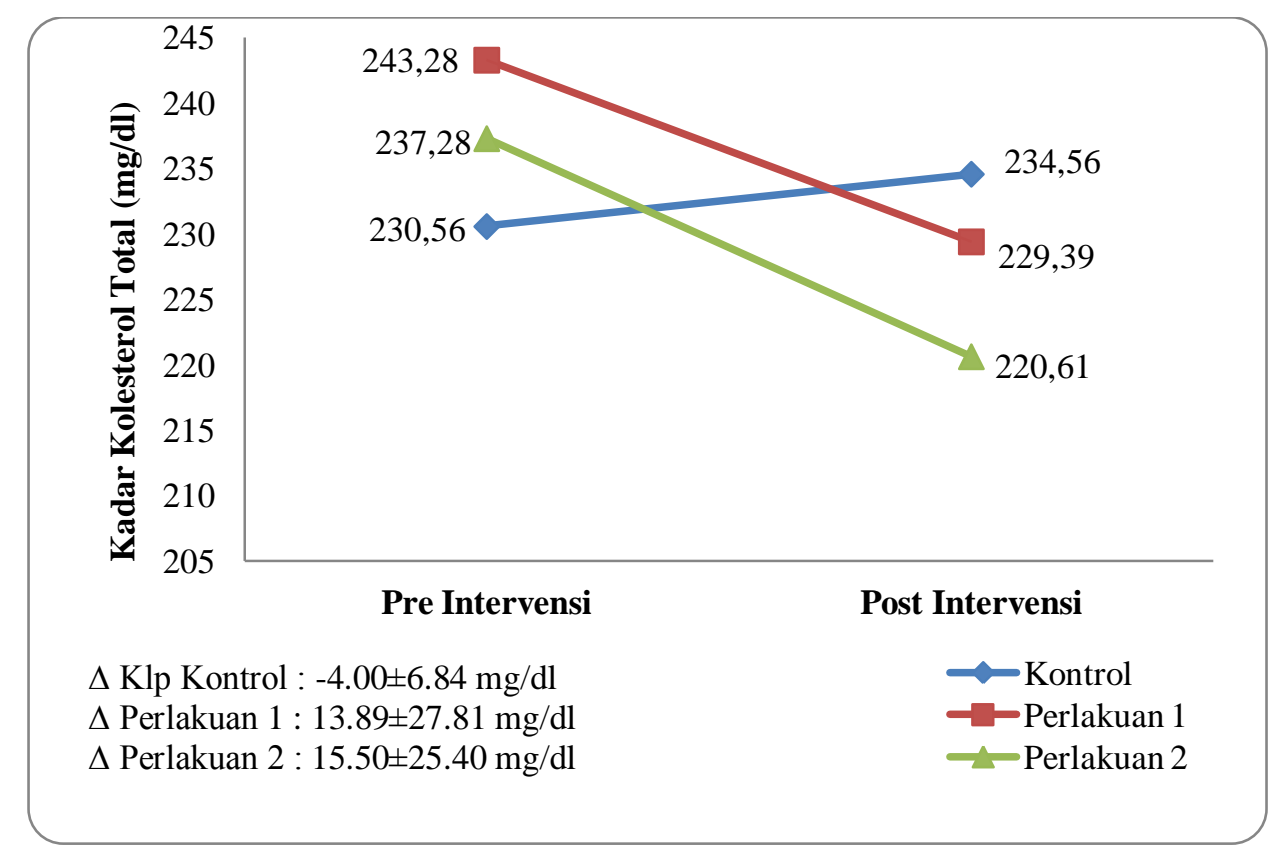

Gambar 1. Perubahan kolesterol total sebelum dan sesudah intervensi

Gambar 1 menunjukkan perubahan kadar kolesterol selama intervensi. Hasil uji KruskalWallis menunjukkan terdapat perbedaan perubahan kadar kolesterol total yang bermakna $(\mathrm{p}=0.012)$ antara ketiga kelompok. Namun tidak terdapat perbedaan penurunan kadar kolesterol total antar kelompok perlakuan 1 dan 2 ( $\mathrm{p}=0.857)$, yang berarti bahwa pemberian nata de coco baik dosis $160 \mathrm{~g} /$ hari maupun $320 \mathrm{~g} / \mathrm{hari}$ selama 14 hari memberikan pengaruh yang sama terhadap penurunan kolesterol total subyek dalam penelitian ini.

\section{PEMBAHASAN}

Karakteristik subyek dalam penelitian ini adalah wanita hiperkolesterolemia dan belum mengalami menopause. Sebagian besar subyek berada pada kelompok umur 40-49 tahun, sementara status gizi subyek sebagian besar adalah overweight, obesitas 1 dan obesitas 2. Namun secara keseluruhan, tidak terdapat perbedaan karakteristik subyek pada awal penelitian, sehingga dapat disimpulkan subyek tergolong homogen.

Gambaran kelompok umur subyek dalam penelitian ini sejalan dengan hasil survey yang dilakukan di Thailand oleh Le et.al yang diteliti pada tahun 1999-2000, yaitu sebanyak 50,3\% wanita hiperkolesterolemia berada pada kelompok umur 30-49 tahun. ${ }^{10}$ Risiko hiperkolesterolemia pada wanita meningkat seiring dengan pertambahan usia dan berat badan. Pada usia subur, wanita terlindung oleh hormon estrogen yang berperan dalam mencegah terbentuknya plak pada arteri dengan menaikkan kadar kolesterol High Density Lipoprotein (HDL) dan menurunkan kadar kolesterol Low Density Lipoprotein (LDL) yang secara langsung akan berpengaruh terhadap kadar kolesterol total. Namun ketika memasuki masa pre menopause hingga menopause, terjadi penurunan kadar hormon estrogen di dalam tubuh, yang meningkatkan risiko terjadinya peningkatan kolesterol serta penyakit jantung dan pembuluh darah. ${ }^{11}$ Status gizi juga merupakan salah satu faktor yang mempengaruhi profil lipid. Pada penderita obesitas, sering terjadi gangguan metabolisme lipoprotein, sehingga terdapat kecenderungan adanya peningkatan kadar kolesterol. $^{2}$

Kadar kolesterol total dan asupan makan subyek sebelum intervensi pada ketiga kelompok tidak menunjukkan perbedaan yang bermakna. Angka kecukupan energi yang dianjurkan untuk kelompok umur 30-49 tahun berdasarkan AKG 2004 adalah 1800 kkal. Rerata asupan energi subyek sebelum dan selama dilakukan intervensi yaitu $1468.2 \mathrm{kkal}$ yang berarti telah memenuhi $81.57 \%$ dari kecukupan yang dianjurkan. Rerata asupan serat per hari seluruh subyek sebelum diberikan intervensi adalah $9.54 \mathrm{~g}$, sementara rerata asupan serat kelompok perlakuan setelah diberikan intervensi mengalami peningkatan yang bermakna menjadi $14.49 \mathrm{~g} /$ hari untuk perlakuan 1 dan $19.54 \mathrm{~g}$ /hari untuk perlakuan 2. Kelompok kontrol juga mengalami peningkatan konsumsi 
serat sebanyak $0.54 \mathrm{~g}$ namun peningkatan ini tidak bermakna secara statistik.

Total konsumsi serat harian subyek pada kelompok perlakuan 2 hampir mendekati anjuran kecukupan serat harian yang direkomendasikan oleh American Dietetic Association (ADA), yaitu 20-35 g/hari atau berdasarkan Dietary Reference Intake (DRI) setara dengan $14 \mathrm{~g} / 1000 \mathrm{kkal}^{12}$ Sebuah studi kohort yang dilakukan di Amerika Serikat selama 10 tahun dengan subyek penelitian wanita usia 37-64 tahun, menunjukkan bahwa pada kelompok wanita yang mengkonsumsi serat ratarata $29.9 \mathrm{~g} /$ hari memiliki risiko $34 \%$ lebih rendah untuk terkena penyakit jantung dan pembuluh darah dibandingkan dengan kelompok wanita yang rata-rata konsumsi seratnya hanya $11.5 \mathrm{~g} /$ hari. $^{13}$

Pemberian nata de coco dengan dosis $160 \mathrm{~g}$ dan $320 \mathrm{~g}$ per hari selama 14 hari terbukti berpengaruh terhadap penurunan kadar kolesterol total pada wanita hiperkolesterolemia. Selisih perubahan kadar kolesterol antara kelompok perlakuan 1 dan 2 adalah $2.78 \mathrm{mg} / \mathrm{dl}$, secara statistik nilai ini tidak bermakna, namun secara deskriptif, nata de coco dengan dosis 320 g/hari memberikan penurunan kolesterol total yang lebih besar dibandingkan dosis $160 \mathrm{~g} /$ hari. Hal ini disebabkan karena pada dosis nata de coco yang lebih besar terkandung serat dengan konsentrasi yang lebih besar pula, sehingga efek hipokolesterolemia serat di dalam tubuh akan meningkat dan dapat menurunkan kadar kolesterol total lebih besar.

Rerata kadar kolesterol total pada kelompok kontrol mengalami kenaikan sebanyak $1.7 \%$. Hal ini kemungkinan disebabkan pada kelompok kontrol, tidak terdapat peningkatan asupan serat seperti yang terjadi pada kelompok perlakuan 1 dan perlakuan 2, sehingga rerata asupan serat kelompok kontrol masih tergolong rendah dan belum mencukupi kebutuhan yang dianjurkan. Asupan serat yang rendah merupakan salah satu penyebab tingginya kadar kolesterol total serum. Hal ini sesuai dengan hasil penelitian yang dilakukan di China yang melihat hubungan asupan serat harian dengan kadar kolesterol total, di mana kelompok yang mengkonsumsi serat rata-rata $7.76 \pm 2.68 \mathrm{~g} /$ hari memiliki kadar kolesterol total lebih tinggi dibandingkan kelompok yang mengkonsumsi serat rata-rata $9.38 \pm 3.08 \mathrm{~g} /$ hari. $^{14}$ Penelitian sejenis yang dilakukan pada wanita dan pria Jepang, di mana pada kelompok wanita, nilai median asupan serat terendah adalah $7.4 \mathrm{~g} / \mathrm{hari}$ dan tertinggi $13.8 \mathrm{~g} / \mathrm{hari}$, berhasil membuktikan bahwa rendahnya asupan serat berhubungan dengan peningkatan kadar kolesterol total dan risiko kematian akibat penyakit jantung dan pembuluh darah. ${ }^{15}$

Jenis serat yang terkandung dalam nata de coco antara lain selulosa, hemiselulosa dan lignin. ${ }^{8,9}$ Jenis serat ini merupakan komponen dinding sel tanaman yang utama, dapat difermentasi oleh bakteri dan bersifat tidak larut air, namun ada sebagian hemiselulosa yang bersifat larut air. Lignin bukan merupakan jenis karbohidrat, melainkan suatu senyawa polimer dengan ikatan fenil propana yang kompleks dan tidak dapat didegradasi oleh bakteri, sehingga tidak dapat difermentasi menjadi asam lemak jenuh rantai pendek. ${ }^{6}$

Sebuah penelitian in vitro yang mereaksikan beberapa sumber serat dengan enzim pencernaan tikus membuktikan bahwa selulosa dapat menurunkan aktivitas enzim pencernaan yang terdapat di usus halus paling efektif, yaitu menurunkan aktivitas enzim amilase, lipase, tripsin dan kimotripsin yang berturut-turut berperan dalam pencernaan karbohidrat, lemak dan protein. ${ }^{5}$ Penelitian in vitro lain juga membuktikan bahwa serat dapat bereaksi dengan enzim proteolitik sehingga mampu menurunkan persentase kasein yang dicerna. ${ }^{5}$

Karbohidrat, lemak dan protein dimetabolisme dalam tubuh untuk menghasilkan asetil Ko-A sebagai produk akhir. Asetil Ko-A merupakan bahan utama dalam sintesis kolesterol. Terhambatnya metabolisme karbohidrat, protein dan lemak yang disebabkan karena adanya penurunan aktivitas enzim pencernaan ini akan berpengaruh terhadap penurunan sintesis asetil KoA sehingga menurunkan sintesis kolesterol di dalam sel. ${ }^{16}$ Selain itu, selulosa juga dapat menghambat absorpsi kolesterol di usus lebih efektif dibandingkan jenis serat lainnya (pektin, alfalfa dan bran), serta berperan dalam pengikatan asam empedu dan meningkatkan pengeluarannya melalui feses. ${ }^{4}$

Penelitian yang dilakukan pada tikus membuktikan bahwa hemiselulosa yang diisolasi dari serat buah kelapa dapat menurunkan kadar kolesterol total serta meningkatkan ekskresi sterol dan empedu melalui feses. ${ }^{9}$ Sementara penelitian yang dilakukan pada hamster menunjukkan peranan lignin dalam mencegah kejadian pembentukan batu empedu melalui mekanisme penurunan tingkat kejenuhan kolesterol dalam empedu, sehingga kristal empedu tidak terbentuk. Selain itu lignin juga dapat meningkatkan ekskresi garam empedu melalui feses. ${ }^{6,17}$ 
Kemampuan selulosa, hemiselulosa dan lignin dalam mengikat garam empedu dan meningkatkan pengeluarannya melalui feses berpengaruh terhadap penurunan kolesterol dalam darah. Garam empedu yang telah terikat pada serat tidak dapat direabsorpsi kembali melalui siklus enterohepatik dan akan disekresi melalui feses, akibatnya akan terjadi penurunan jumlah garam empedu yang menuju ke hati. Penurunan ini akan meningkatkan pengambilan kolesterol dari darah untuk disintesis kembali menjadi garam empedu yang baru yang berakibat pada penurunan kadar kolesterol dalam darah. Pengikatan empedu juga dapat merubah senyawa cholic acid menjadi chenodeoxycholic acid yang dapat menghambat kerja enzim 3-hydroxy 3-methylglutaryl (HMG) CoA reductase. Penurunan fungsi kerja enzim ini akan mengakibatkan terjadinya penurunan sintesis kolesterol di hati dan dapat menurunkan kadar kolesterol total serum. ${ }^{6}$ Selulosa dan hemiselulosa dapat difermentasikan di dalam kolon lebih lambat dibandingkan serat larut air. ${ }^{6}$ Produk akhir hasil fermentasi serat adalah berbagai senyawa asam lemak jenuh rantai pendek, seperti asetat, propionat dan butirat yang dapat menekan sintesis kolesterol di dalam hati. ${ }^{6,17}$

Adanya penurunan kadar kolesterol total setelah intervensi selain dipengaruhi oleh serat nata de coco, dipengaruhi juga oleh jumlah serat yang dikonsumsi subyek sehari-hari. Fungsi serat nata de coco selama intervensi adalah untuk membantu meningkatkan kecukupan serat subyek sehingga memenuhi anjuran yang direkomendasikan.

World Health Organization (WHO) menganjurkan konsumsi serat total (total dietary fiber) sebaiknya tidak lebih dari $40 \mathrm{~g} /$ hari dan asupan serat tidak larut air (non-starch polysaccharides) sebaiknya $16-24 \mathrm{~g} / \mathrm{hari}^{18}$, karena konsumsi serat yang berlebih dikhawatirkan dapat menimbulkan defisiensi zat gizi lainnya, terutama zat gizi mikro. Hal ini dapat terjadi karena adanya kandungan fitat dalam serat yang dapat mengikat mikronutrien sehingga menghambat absorpsinya. ${ }^{19,20}$ Selain itu konsumsi serat yang berlebih juga dapat menimbulkan gangguan saluran cerna seperti kram perut, kembung, diare dan konstipasi. Dalam penelitian ini, kontribusi serat nata de coco terhadap rerata asupan serat per hari tidak melebihi dosis yang dianjurkan, sehingga dampak tersebut dapat diabaikan.

\section{SIMPULAN}

Pemberian nata de coco dengan dosis $160 \mathrm{~g}$ (serat $4.8 \mathrm{~g}$ ) dan $320 \mathrm{~g}$ (serat $9.6 \mathrm{~g}$ ) per hari selama 14 hari berpengaruh terhadap penurunan kadar kolesterol total pada wanita dengan hiperkolesterolemia secara bermakna. Tidak ada perbedaan penurunan kadar kolesterol total yang bermakna antara kedua dosis.

\section{SARAN}

1. Wanita dengan hiperkolesterolemia dapat mengkonsumsi nata de coco basah sebagai salah satu sumber serat untuk memenuhi kebutuhan serat harian yang dianjurkan dan sebagai makanan alternatif yang dapat menurunkan kadar kolesterol total dengan dosis minimal $160 \mathrm{~g} / \mathrm{hari}$.

2. Penelitian lebih lanjut perlu dilakukan dengan subyek penelitian tidak hanya pada wanita hiperkolesterolemia, sehingga peran serat nata de coco dalam menurunkan kolesterol dapat dimanfaatkan secara umum.

\section{DAFTAR PUSTAKA}

1. Truswell AS. Cholesterol and beyond, the research on diet and coronary heart disease 1900-2000. New South Wales: Springer;2010.p.9-11.

2. Fletcher B, Berra K, Ades P, Braun LT, Burke LE, Durstine JL, et al. Managing abnormal blood lipids, a collaborative approach. Circulation. 2005;112:3184-3209.

3. Laporan Hasil Riset Kesehatan Dasar (RISKESDAS) Nasional 2007.

4. Sugano M, Ikeda I, Imaizumi K, Lu YF. Dietary fiber and lipid absorption. In : Kritchevsky D, Bonfield C, Anderson JW, editors. Dietary Fiber Chemistry, Physiology, and Health Effects. New York: Plenum Press; 1990.p.137-153.

5. Schneeman BO, Gallaher D. Effects of dietary fiber on digestive enzymes. In : Spiller, editor. CRC Handbook of Dietary Fiber in Human Nutrition $3^{\text {rd }}$ edition. New York: CRC Press; 2001.p.277-283.

6. Gropper SS, Smith JL, Groff JL. Advanced nutrition and human metabolism. $5^{\text {th }}$ edition. USA:Wadsworth Cengage Learning; 2009.p.107123.

7. Mesomya W, Pakpeankitvatana V, Komindr S, Leelahakul P, Cuptapun Y, Hengsawadi D, et al. Effects of health food from cereal and nata de coco on serum lipids in human. Songklanakarin J. Sci. Technol 2006, 28(Suppl. 1):23-28.

8. Ramadhan F. Pengaruh pemberian nata de coco terhadap kadar kolesterol total dan trigliserida pada tikus hiperkolesterolemia. Artikel Penelitian 
Program Studi Ilmu Gizi Fakultas Kedokteran UNDIP Semarang. 2011.

9. Sindhurani JA, Rajamohan T. Hypolipidemic effect of hemicelulose component of coconut fiber. Indian J Exp Biol. 1998 Aug; 36(8):786-9.

10. Le D, Garcia A, Lohsoonthorn V, Williams MA. Prevalence and Risk Factors of Hypercholesterolemia among Thai Men and Women Receiving Health Examinations. Southeast Asian J Trop Med Public Health. 2006; Vol 37:No.5.

11. Soeharto I. Pengaruh Usia dan Gender terhadap Kolesterol. Dalam : Serangan Jantung dan Stroke. Jakarta : PT Gramedia Pustaka Utama; 2004.hal.168-178.

12. Dreher ML. Dietary Fiber Overview. Indiana : Mead Johnson Nutritionals/Bristol-Myers Squibb Company, Evansville. 2001.

13. Wolk A, Manson JE, Stampfer MJ, et al. Longterm intake of dietary fiber and decreased risk of coronary heart disease among women. JAMA 1999;281:1998-2004.

14. Ruixing Y, Qiming F, Dezhai Y, Shuquan L, Weixiong L, Shangling P, et al. Comparison of demography, diet, lifestyle, and serum lipid levels between the Guangxi Bai Ku Yao and Han populations. J. Lipid Res. 2007. 48: 2673-2681

15. Eshak ES, Iso H, Date C, Kikuchi S, Watanabe $Y$, Wada Y, et al. Dietary fiber intake is associated with reduced risk of mortality from cardiovascular disease among Japanese men and women. J. Nutr. 2010. 140: 1445-1453.

16. Mayes, PA. Sintesis, Pengangkutan dan Ekskresi Kolesterol. Dalam : Murray RK, Granner DK, Mayes PA, Rodwell VW, editors. Biokimia Harper. Edisi 24. Jakarta: Penerbit Buku Kedokteran EGC; 1997.hal.277-89.

17. Jenkins AL, Vuksan V, Jenkins DJA. Fiber in the treatment of hyperlipidemia. In : CRC Handbook of Dietary Fiber in Human Nutrition $3^{\text {rd }}$ edition. New York: CRC Press; 2001.p.401-412.

18. Nishida C, Uauy R, Kumanyika S, Shetty P. The joint WHO/FAO expert consultation on diet, nutrition and the prevention of chronic diseases: process, product and policy implications. Public Health Nutrition: 7(1A), 245-250. 2004.

19. Harland BF, Oberleas D. Effect of dietary fiber and phytate on the homeostasis and bioavailability of minerals. In : CRC Handbook of Dietary Fiber in Human Nutrition $3^{\text {rd }}$ edition. New York: CRC Press; 2001.p.161-169.

20. Kasper H. Effect of dietary fiber on vitamin metabolism. In : CRC Handbook of Dietary Fiber in Human Nutrition $3^{\text {rd }}$ edition. New York: CRC Press; 2001.p.173-179. 